\title{
Mekana Özgü Sanatta Yeni Stratejiler: Berlin'deki Güncel Pratikler
}

\author{
Seda ÖZEN TANYILDIZI*
}

O̊zet

Günümüzde sanatın mekanla olan ilişkisine dair güncel durumları tanımlamak oldukça zor. Global düzeyde, sanat, mimari ve tasarım alanlarını kesin sınırlarla birbirinden ayıramadığımız, melez disiplinler ve uzmanlıkların ortaya çıktığı bir süreçten geçiyor olmamız bu durumun başlıca nedenlerinden birisi olarak görülebilir. Bu disiplinler arası çok yönlü ortam içerisinde, galeri ve müzeleri, kamusal alanları ya da alternatif mekanları, sanatsal üretimlerinin merkezine yerleştireren sanatçıların sayısı da son dönemde dikkat çekici bir oranda artmıştır. Bu çalışmanın amacı, mekana özgü sanata ilişkin yeni alternatiflerin günümüz sanat ortamı içerisinde nasıl bir konuma yerleştiğini bağlam, melezleşme, kavram, ölçek, izleyici ve finansal destek gibi son zamanlarda sanat çevrelerince ele alınan trend başlıklar altında analiz ederek güncel verilere ulaşmaktır. Çalışma kapsamında yer verilen sanatçı örnekleri Almanya'da gerçekleştirilmiş olan araştırma projesinin çıktılarını yansıtmaktadır. Metinde bahsi geçen örneklerin pek çoğu birebir görüşme ve diyaloglarla elde edilen veriler ışığında oluşturulmuştur. Bu nedenle çalışmanın en önemli özelliklerinden birisi birincil kaynakların deneyim ve görüşlerine dayanıyor oluşudur.

Anahtar Kelimeler: Mekana Özgü Sanat, Kamusal Alan, Mekan, Mimari, Melezleşme, Müdahale.

\section{New Strategies in Site-Specific Art: Contemporary Practises in Berlin}

\section{Abstract}

Nowadays, it is quite difficult to define the current situation regarding the relationship between art and site. At a global level, the fact that we undergo a process when we cannot definitively distinguish the fields of art, architecture and design, may be regarded as one of the reasons for this situation. In this interdisciplinary and multifaceted environment, the number of artists who centre galleries, museums, public spaces or alternative places in their artistic production has remarkably increased. The aim of this study is to analyse the position of new alternatives regarding site-related art in today's art environment under the trending titles of context, hybridisation, concept, scale, viewer and financial support that current art communities often handle and discuss to obtain current data. The examples of artists in this study reflect the data of a research project carried out in Germany. Most of the examples have been formed in light of the data obtained through face-to-face meetings and dialogues. Therefore, one of the most important features of this study is that is based on the experiences and opinions of primary sources.

Keywords: Site-specific Art, Public space, Space, Architecture, Hybridisation, Intervention. 


\section{Bağlam}

Heykel ve resim gibi geleneksel anlayışlardan uzaklaşarak, farklı yaklaşımlar ve yeni stratejilerle hareket etmeye başlayan sanat eserlerinin hangi bağlama yerleştiği konusu günümüzde oldukça kompleks bir hale gelmiştir. Bu çetrefilli durum, sanat ve mekan ilişkisine dair yeni kategoriler, sınıflandırmalar, başııklar ya da tanımlar önerilmesi ihtiyacını doğurmuştur. Sanatçı Robert Irwin (1985: 217-218) bu konuyu 'Site-dominant (Mekanın dominant olduğu), Siteadjusted (Mekana göre ayarlanmış), Site-specific (Mekana özgü), Site-conditioned/determined (Mekanın belirlediği)' gibi başlıklarla kategorize etmiş; sanat tarihçisi Pof. Kaye (2000: 1) 'semiyolojik bağlamda' değerlendirmiş; bir diğer sanatçı Florentijn Hofman (2005: 9) 'lokasyonal ilişkiler' çerçevesinde tanımlamıştır. Sanatın mekanla olan ilşkisini tanımlamaya ve sınıflandırmaya çalışan daha pek çok örnek mevcuttur. Princeton Üniversitesi'nde gerçekleştirilen sanat ve mimarlık konulu 'Retracing Expanded Field' konferansı, sanatın mekanla olan ilişkisini irdeleyen son yılların önemli etkinliklerinden birisidir. Burada da yine sanat ve mimari konulu yayınlar ve sergilerin sayısındaki artışa oranla, bu alanı tanımlamaya çalışan örneklerin çok dar kapsamlı olduğuna vurgu yapılmaktadır (Papapetros ve Rose, 2014: xiii - xiv; Wallace ve Wendl, 2013: 14 -15).

Bugün artık sanat, mimari ve tasarım alanlarındaki melezleşme mekana özgü sanatı yeni bir platforma taşımıştır. Farklı araçları bir arada kullanarak melez yapıda çalışmalar ortaya koyan yeni nesil sanatçılar, sanat ve yaşam ilişkisine dair çok yönlü sonuçlar ortaya koymakta, galeri ve müzeler dışındaki kamusal alanda da, izleyicinin sanat eseri ile aktif biçimde bir aradalığını sağlayan çalışmaları ile mekan kavramına yeni açılımlar sağlamaktadırlar. Artık, kütüphanelerden spor komplekslerine, hava alanlarından opera binalarına, bankalardan restoranlara kadar pek çok mekan, sanatçıların çalışma alanları haline gelmiştir (Ellegood, 2014: 7). Kısacası, mekana özgü sanat, hem kavramsal hem biçimsel hem de kurumsal açıdan 1950'lerden günümüze dek evrimleşerek bugünkü yeni halini almıştır.

Mekan ve sanat arasındaki bağlantının böylesine geniş bir alana yayıldığı durumda sanatçıların da üretimle- rini katı, kesin, değişmez bağlamlara yerleştirmeyi uygun bulmadıklarını söylemek yanlış olmayacaktır. Örneğin, almış oldukları eğitim dolayısıyla, sanatsal yaklaşımlarında mimarlık, sanat tarihi, heykel gibi farklı disiplinlerin sentezini yansıtan Anna Borgman ve Candy Lenk ikilisi, çalışmalarını tarihsel ve biçimsel olmak üzere iki farklı bağlamsal seviyeye yerleştirmektedirler (Resim 1). Öyle ki, galeri ya da müze mekanlarında dahi, mimari yapıyı bu seviyeleri kullanarak analiz etmekte ve sonuçta bilindik sergileme yöntemlerinden uzak, mekanın aktif işlevsel yapısına parallellik göstermeyen işler oluşturmaktadırlar. Tarihsel verilerle şekillenmiş olan Rekonstruktion yerleştirmesi galeri iç mekanını kullanmak yerine mimariye ait dış cepheyi kullanmaktadır. Borgman ve Lenk'in birçok çalışması mekana özgü nitelikte olmasına karşın, sanat işine ait anlamın başka bir atmosferde yeni anlamalara karşılık geleceği düşüncesi de projelerinde değerlendirilmektedir. 1

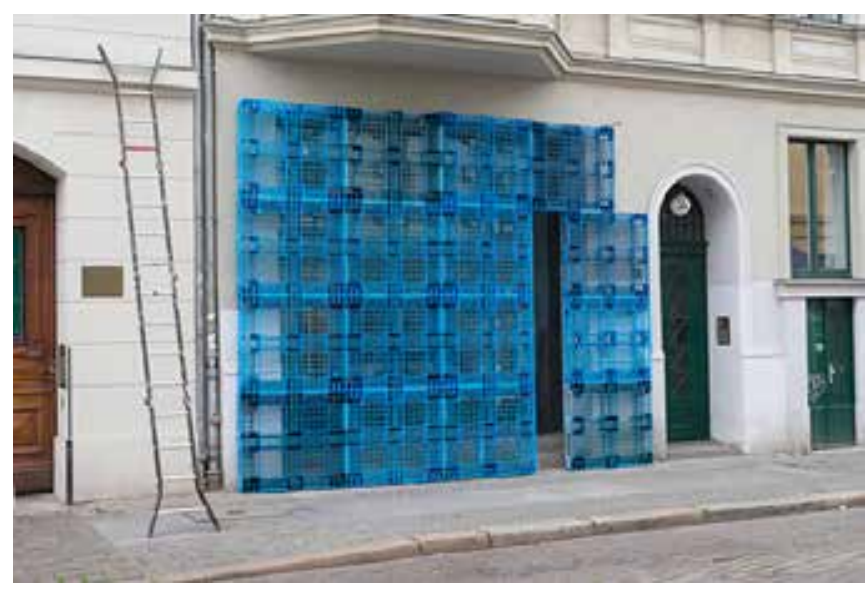

Resim 1. Anna Borgman / Candy Lenk, 'Rekonstruktion', Galerie Aquabit, Berlin, Almanya, 2015.

Kurgusal yapıda mekana özgü işler üreten sanatçı Christian Hasucha ise çalışmalarını 'Kamusal alanda müdahale' başlığı altında toplamaktadır. Ancak sanatçı bu genel tanımlamanın yanı sıra, 'olaylar, implantasyonlar, atıflar ve öneriler' alt başlıklarını kullanmakta, bu sayede işlerin hangi bağlamda okunması gerektiğine dair bir yönlendirme sunmaktadır. ${ }^{2}$

1980’li yıllardan beri, mekana özgü ve müdahale çalışmaları üretmekte olan Eberhad Bosslet’in eserleri ‘kons- 
trüksiyon ve yerleşim/konut’ temaları çerçevesinde bir biçimde dış ve iç, özel ve kamusal, kentsel ve kırsal mekanlar bağlamlarına yerleşmektedir (Resim 2). 3

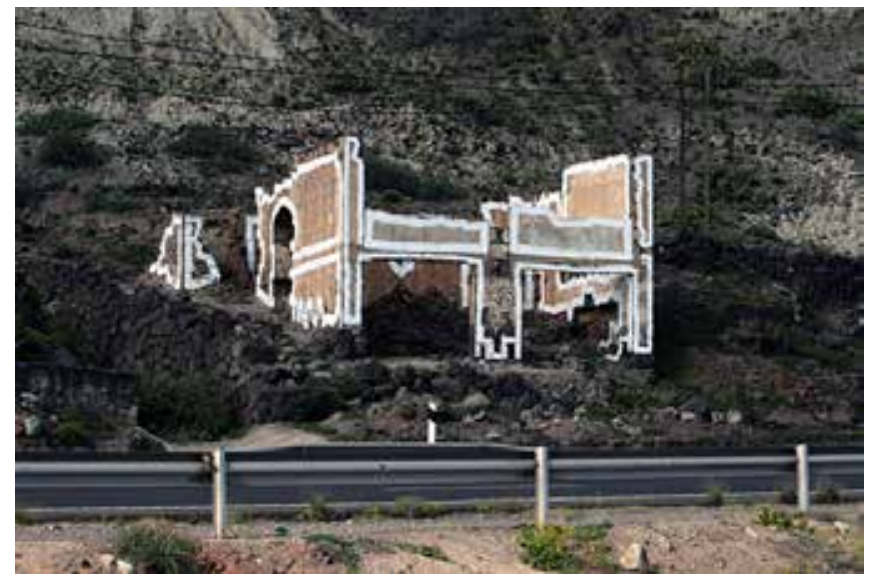

Resim 2. Eberhard Bosslet, 'Reformation VII', Gran Canaria, Autovía GC-2 28 7‘48.33“ N; 15²8‘31.55“ W, 2009.

Endüstriyel malzemelerden oluşan yerleştirmeleri ve mimari plan estetiğine sahip çizimleriyle tanınan Franka Hörnschemeyer çalışmalarının varoluşsal durumunu mekanın verilerine olan bağlantısıyla açıklamaktadır. Sanatçı, spesifik bir mekanın bilgisiyle ilerlemekte ve bu bilgiyi sanat işini oluşturan sürecin bir parçası olarak ele almaktadır. $^{4}$

Geleneksel sanat anlayışlarının (resim, heykel vs.) mekansal ilişkiler aracılığıyla yeni bir bağlama taşındığı durumlar, bugün oldukça çarpıcı örneklerle karşımıza çıkmaktadır. Anne Peschken ve Marek Pisarsky tarafından 2005 Münsterland Heykel Bienali için tasarlanmış mobil heykel örneğinde olduğu gibi: bu çalışmada sanatçılar mekanın lokasyonunun tarihsel olarak okunmasını sağlayan yeni bir araç önermektedirler (Resim 3). Tarihsel veriler taşıyan geleneksel anıt mantığını yansıtan sabit bir heykelden ziyade, kullanıcıların / katılımcıların yükledikleri tarihsel mesajları yansıtan mobil bir heykel üretmeyi tercih etmişlerdir. Beş yıl boyunca bölgede dolaşan bu iş, fiziksel açıdan topografik ve mimari bağlamlarla ele alınabileceği gibi, üzerinde taşımakta olduğu değişken veriler dolayısıyla tarihsel ve sosyal durumlarla da değerlendirilebilir. ${ }^{5}$

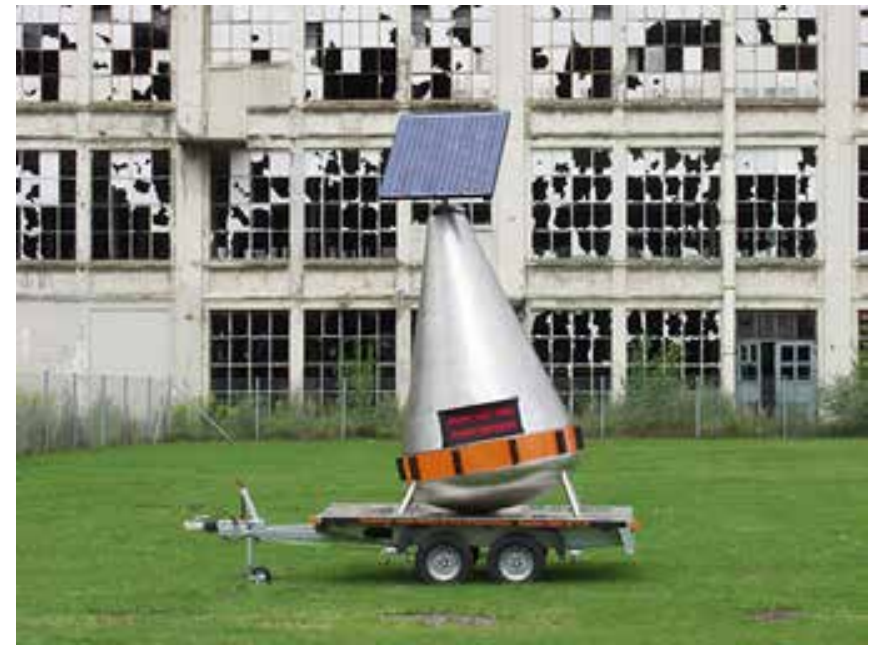

Resim 3. Anne Peschken / Marek Pisarsky, 'Wandering Buoy', Biennial Münsterland, 2005.

Örneklerden de anlaşılacağı gibi, sanatçılar farklı amaç ve hedefler doğrultusunda, daha çok mekanı yeniden yorumlama, canlandırma ya da mekana yeni bir kimlik kazandırmaya yönelik uygulamalarla iletişimsel bir yaklaşım oluşturmanın peşinde ilerlemektedir. Bu çeşitlilik içerisinde bağlamsal yapıları keşfetme durumu güncel sanatın melez haliyle ilişkilendirilebilir.

\section{Melezleşme}

Yukarıda bahsedilen örneklerden yola çıkarak sanat ve mekana dair tanımlamalardaki değişken durumu sanatçıların sınırları olmayan açı bir bağlamsal alanda ilerliyor oluşuna bağlayabiliriz. Günümüzde mekana özgü sanatı yalnızca sanatın parametreleriyle değerlendirerek kavrayabilmek mümkün değildir. Sanatçılar, tasarım ve mimari alanlarına ait verileri kullanmakta ve zaman zaman bu alanlardan profesyonellerle birlikte projeler üretmektedirler. Dolayısıyla bu çalışmalar ancak disiplinler arası bir yapının verileriyle değerlendirilebilir. Günümüzde bu türden bir alışverişin sonucu olarak gerçekleştirildiği mekanının rolünü ve işlevini radikal bir biçimde değiştiren mimari, sinema, tasarım, tiyatro, gibi pek çok farklı alandan beslenen ve zaman zaman çok büyük ölçeklere ulaşan sanat işleri üretilmeye başlamıştır. Tüm bunlara ek olarak, büyük ölçekli çalışmalar, sanatçıların bilim, mühendislik, şehir planlama gibi alanlardan uzmanlarla birlikte hareket ettikleri bir işbirliği sürecinin ürünleri olarak karşımıza çıkmaktadır (Manco, 2014: 16). Sanatçllar her ne kadar kavram ve işlev 
açısından bu uzmanlık alanlarına kıyasla çok daha bireysel ve özgür bir alanda ilerliyor olsa da, böylesi işbirlikleri ile gerçekleştirdikleri projeler kapsamında diğer alanlarla bir takım ortak stratejiler paylaşmaktadırlar.

Yukarıda bahsi geçen Borgman ve Lenk örneğine dönecek olursak, çalışmaların sanat, tasarım ve mimari kesişimine yerleşmesi ve mühendislik bilgisinden faydalanması bakımından bu konuyu örneklediğini söylemek mümkündür. Ancak burada işlerin tam olarak hangi noktada diğer alanlardan ayrışarak 'sanat etiketini' aldığı konusu önemlidir. Bu anlamda Borgman ve Lenk 'sanatsal tasarım'ın biçimsel özellikler ile işlevi merkeze aldığını, 'sanat'ın ise durumları ve problemleri tanımlayarak izleyicileri kendi cevaplarını bulabilecekleri pozisyonlara yerleştirdiklerini vurgulamaktadır. 6

Elbette ki bu karşılıklı değiş-tokuşun bir sonucu olarak tasarımcılar, mimarlar ve mühendisler tarafında da benzer bir durum gözlenmektedir. Onlar da sanat üretimine ait düşünsel, kavramsal ve estetik değerleri kendi üretim süreçlerine eklemektedir. Bu sayede, yoğunluklu olarak sanat ve mimarlık alanlarının birardalığından faydalanan melez yapıda çarpıcı işler ortaya çıkmaktadır (bkz. Papapetros ve Rose, 2014: xiii - xiv; Ellegood, 2014: 11; Lavin, 2011: 67-68; Fernie, 2006: 9-14).

Çalışmaları çoğunlukla sosyo-politik kavramlar üzerinden gelişen Maria Linares'in Sanat ve Mimarlık programı kapsamında bir spor merkezi için tasarladığı Hirsch Rot isimli çalışması iç mimarlık ve görsel iletişim alanlarından beslenen bir yapıdadır (Resim 4). Teması 'önyargı' ve 'ayrımcılık' gibi kavramlarla şekillenmiş olan bu çalışma sporculara ait görüşlerin metinsel bir ifadesi biçiminde karşımıza çıkmaktadır. Linares, çalışmanın röportaj sürecini bir etnolog ile birlikte hazırlamış ve yürütmüştür. ${ }^{7}$

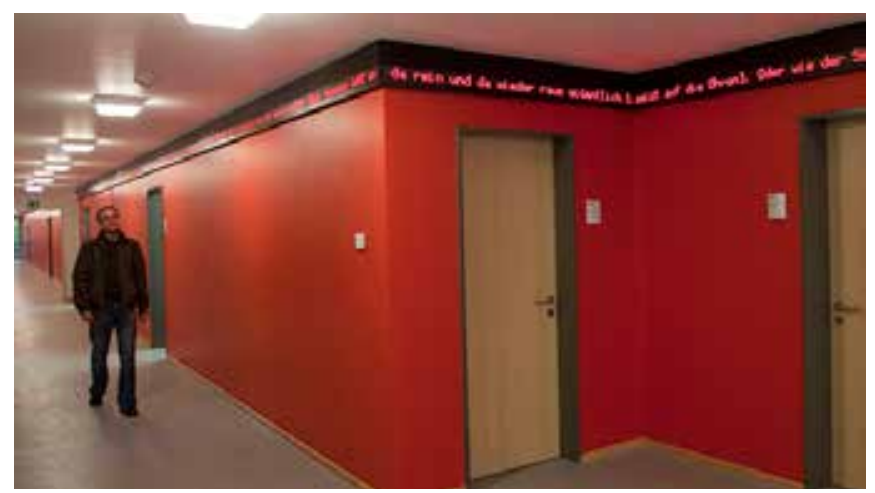

Resim 4. Maria Linares, 'Hirsch Rot’, Almanya, 2014.
Benzer bir işbirliği Svea Duwe'nin görsel sanatlar, tiyatro ve film alanlarını bir platformda buluşturduğu Liebe. Wahr. Jetzt isimli çalışmasında da gözlemlenebilir (Resim 5). Sanatçı, performans kategorisine yerleştirebileceğimiz bu işinde, sahnedeki iki oyunucunun eylemlerini ekranlara yansıtarak gerçek zamanlı/mekanlı teatral bir gösterinin içerisinde yeni bir 'sanal aksiyon mekanı' yaratmaktadır. Sanatçının kamera açılarıyla oynarak yarattığı algısal kurgular oyuncular için üstesinden gelmesi zor bir durum yaratırken, izleyiciler de aynı anda iki farklı sanat anlayışıyla (tiyatro ve video) karşı karşıya kaldıkları başka bir zorlu süreci deneyimlemektedirler. 8

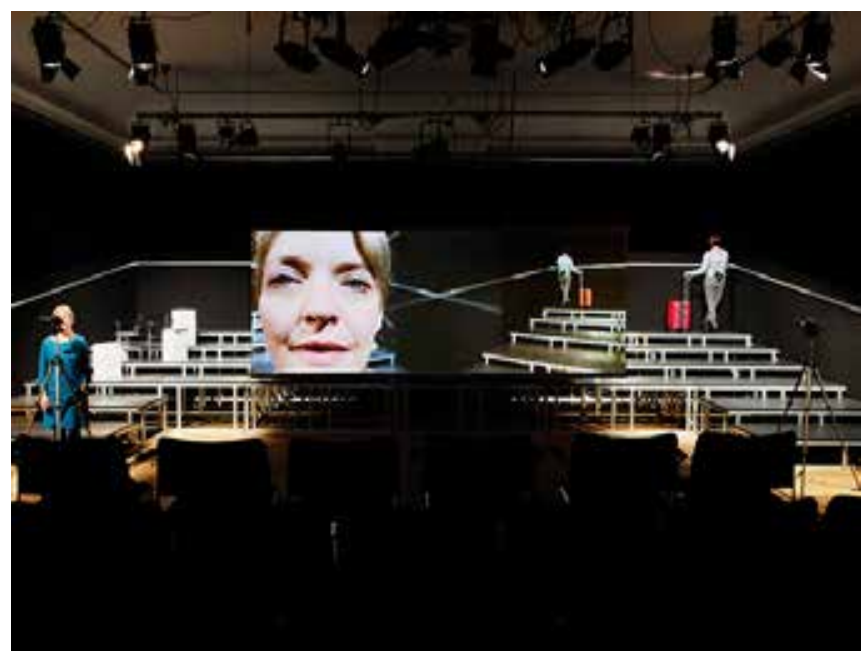

Resim 5. Svea Duwe, 'Liebe. Wahr. Jetzt', Societaetstheater Dresden, Almanya, 2014.

Örneklerden anlaşılacalacağı gibi, her ne kadar bu çalışmanın temellendiği örnekler sanat başlığı altına yerleşiyor olsa da, bu güncel pozisyonlara zemin hazırlayan nedenler büyük ölçüde bahsi geçen diğer disiplinler için de geçerlidir. Ilfeld, (2014: 7-8) MoMA, Tate Modern ya da Center Pompidou gibi sanat kurumlarında sergilenen sanatçı retrospektiflerinin global bir iletişim ağı yansıttığına ve çapraz-disiplinli söylemin giderek yaygınlaştı̆̆ına değinmektedir. Ilfeld (2014: 11) ayrıca, bu duruma zemin hazırlayan bir diğer önemli nedenin sanat okullarının sürekli bir biçimde yeni disiplinler arası programlar ve uzmanlık alanları önermeleri ve sanatsal uygulama bazlı doktara çalışmalarını desteklemeleri olduğuna işaret edip hem yazınsal alandaki rollerin (sanat eleştirmenleri, tarihçiler ve 
blog yazarları) hem de mimari, sanat ve tasarım alanlarının (Anish Kapoor, Antony Gormley, Usman Haque, Do Ho Suh, ve Ai Weiwei'nin çalışmalarına atıfta bulunarak) sınırlarının bulanıklaştığına vurgu yapmaktadır.

Bugün artık 'mekan' sanatçılar için yalnızca inşa edilmiş bir alan olarak değil, aynı zamanda kentsel, sosyal ve siyasi kavramlarla ele alınan bir konu haline gelmiştir. Sanatçılar, mimari ya da kentsel mekan ile üretim pratikleri arasında bir bağlantı arayışına girmiştir. Bu anlamda kamusal alana yerleşen işlerin iletişimsel bir bağlam içerisinde değerlendirilmesi gerekmektedir. Bu alanlarda gerçekleştirilen yerleştirmeler, galeri ya da müze mekanında sergilenen işlerden çok daha kapsamlı ve kompleks bir kavrayış yapısına ihtiyaç duymaktadır. Bunun başlıca sebebi kurumsal yapıların bilindik kurallarını kamusal alanlara uygulayamayışımızdır. Sanat işinin nasıl deneyimleneceğine ilişkin geleneksel kavrayış biçimlerini, herbiri farklı işlevlere ve tarihsel süreçlere sahip alternatif alanlara uygulamak münkün değildir. Bu türden alanlarda sanat deneyimi farklı zamansal ve mekansal ilişkiler vasıtasıyla yeni nitelikler kazanmaktadır. Sonuç olarak burada bahsedilen örneklerdeki uygulamalar ortak bir noktada birleşmektedir: tüm çalışmalar sanat, tasarım ve mimari sınırlarında gezinmektedirler. Bu noktada sanat ve mimari arasındaki etkileşim, işlevselliği estetik ile birleştirmektedir.

\section{Kavram}

1950 ve 60’lı yıllarda galeri ve müzelere karşı kurumsal eleştirinin biçimsel bir yansıması olarak ortaya çıkmış olan mekana özgü sanat, çoğunlukla bu ortaya çıkış noktası üzerinden 'politik kavramlarla' değerlendirilmiş ve yorumlanmıştır (O'Doherty, 1999: 87-108). Bu dönemde hem kurumsal galeri ya da müze mekanlarında gerçekleştirilen ve eleştirel yönü ağır basan çalışmalar, hem de kamusal alanlardaki alternatif mekanlarda oluşturulan işler, sanatın bulunduğu yer ile olan ilişkisinin pek çok açıdan sorgulanmasını sağlamıştır. Sanatçılar bu türden bir eleştiriyi aktarmak için kurumsal eleştiri odaklı kavramlar çerçevesinde mekanı bir araç olarak kullanmışlardır. Böylece 0 güne kadar beyaz küp içerisindeki nesneler şeklinde kabul gören sanat, müze bağlamından koparılarak kurumsal yapıdan ayrı bir biçimde değerlendirilir hale gelmiştir. 1980'li yıllarda Reagan ve Thatcher hükümetleri döneminde ortaya çıkan serbest piyasa ekonomisi ile birlikte Amerika'da ve İngiltere'de şirketler yüksek kültür üzerinde oldukça hakim bir duruma gelmiştir. 'Mimaride sanat' konusu dahilinde sanat bu işlevini özel sermaye aracı olarak yerine getirmeye başlamış ve mekana özgü sanat yeni kavramlar üzerinden değerlendirilmeye başlanmıştır. (Wu, 2002: 1-6) Kısacası, sanatçılar tarafından başlatılan mekana dair yeni öneri ve stratejiler, ticari galerilerce takip edilmiştir. Son olarak bugün bu süreç sanat müzelerince ve devlete ait bazı organizasyonlar tarafından (sanat fonları, yarışmalar vs.) yeniden kurumsallaştırılmıştır (Greenberg, 2005: 246-259).

Kurumsallaşma sürecindeki bu dönüşümün ardından, mekana özgü sanat, çok yönlü dünya kavrayışının bir parçası olarak, sanatçıların yeni kavramları keşfettikleri deneysel bir alan haline gelmiştir (Rugg, 2010: 1). Bugün artık teknoloji, bilim, medya, mimari ve tasarım gibi güncel sosyal hayatın belirleyicileri olan meseleler, sanatçıların mekanlar üzerinden hem kavram hem de materyal bağlamında değerlendirdiği konular arasında yer almaktadır.

Bu sanat anlayışında kavramları görsel bir ifadeye dönüştürecek olan metaryal ve medyaların mekanın fiziksel koşullarına göre şekillendiğini gösteren birçok örnek var. Bu anlamda bazı sanatçılar kendilerini bir kavram ya da malzemeye bağlı kalmak durumda hissetmemektedirler. Ancak, buna karşılık, malzemenin ve kavramların işlerin bütününe bakıldığında bir imzaya dönüştüğü örnekler de mekana özgü sanat içerisinde önemli bir yer tutmaktadır.

Örneğin, çalışmalarının genelinde malzeme ve renk tutarlılığı gözlemlenen Oliver Oefelin, çoğunlukla benzer konuları ve formları farklı mekansal kurgulara adapte ederek 'illüzyon ve gerçeklik kayması' temaları üzerine temellenen mekana özgü çalışmalar üretmektedir (Resim 6). Sanatçının endüstriyel malzemelerin biyolojik organizmalardan türetilen formlara dönüştürüldüğü çalışmaları, yeni mekanlar oluşturmak için kullanılırken, bazı durumlarda da varolan mekanlara yerleştirilmektedir. Her iki bağlamda da sanatçı çalıştığı lokasyonun verilerinden faydalanmaktadır. ${ }^{9}$ 


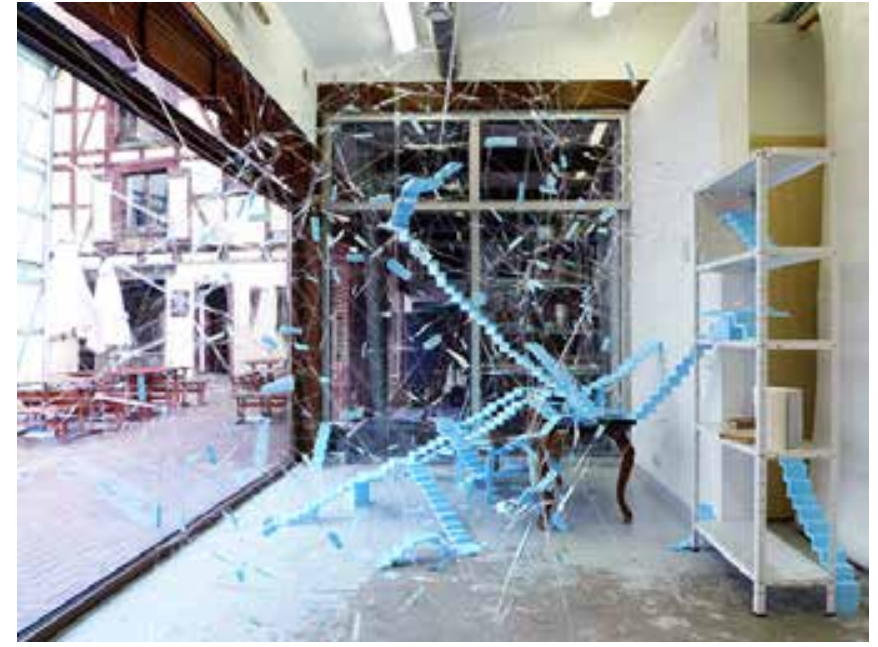

Resim 6. Oliver Oefelein, 'Sticky Cloud Klaipeda', KKKC-Gallery, Litvanya, 2011.

Benzer bir durum, mimariyle ilkişkili duvar çalışmaları üreten Renate Wolff'un yaklaşımında da gözlemlenebilir. Sanatçının eserleri günlük yaşantılarımızı biçimlendiren ritmler üzerine temellenmektedir. Her ne kadar malzeme ve sanatsal yaklaşım açısından sabit bir yapı sergiliyor olsa da, her bir çalışma üretildiği mekana spesifik özellikler taşımaktadır. 10

Bir diğer sanatçı Nadja Schöllhammer iki boyutlu resim pratiğini üç boyutlu mekanlara dönüştürerek oluşturduğu yerleştirmelerinde işin bulunduğu alandan çok kullanılan materyal ön plana çıkmaktadır (Resim 7). Sanatçı mekana ait verilerden yola çıkmak yerine, kendi oluşturduğu özgün özelliklere sahip formları mekan içerisinde bir araya getirmekte, böylece çizimlerin katmanlara dönüştüğü üç boyutlu mekansal bir kurgu yaratmaktadır. 11

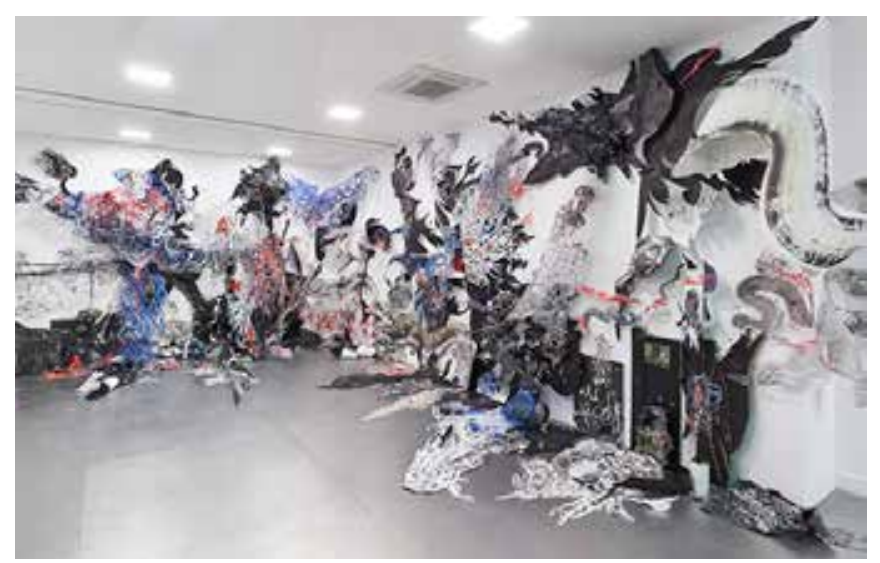

Resim 7. Nadja Schöllhammer, 'Soul Inhaler', Arter, İstanbul, Türkiye, 2015
Schirin Kretschmann da benzer şekilde resim pratiğine ait renk öğesini hem kavramsal hem de biçimsel boyutta mekansal bir platforma taşımaktadır. Sanatçı mekanın varolan verileri üzerinden hareketle elde ettiği bilgiyi bir tür renk koduna aktararak mekanları ya da onlara ait elemanları işaretlemektedir. Schöllhammer örneğinden farklı olarak Kretschmann süreci oluşturan ilk adımın işi gerçekleştirileceği mekan üzerine yaptığı araştırmalar ve incelemeler olduğunu vurgulamaktadır. 12

\section{4. Ölçek}

Son zamanlarda üzerinde çokça durulan bir diğer kritik mesele de ölçek konusudur. Bu konu üzerine pek çok görüşe rastlıyoruz. Örneğin Foster (2011), son zamanlarda popüler olan büyük ölçekli sanat işleri ve bunları sergileyen kurumlar üzerinden 'mekansal yücelik' konusunu değerlendirmektedir. Resim, heykel ve video sanatının mimari ile olan ilişkisinin müzelerin etkisine bağlı olduğunu ifade eden Foster (2011: VII) aynı zamanda hükümetler, şirketler ve sanat merkezlerinin iş dünyasının yatırımlarını çekmek ve şehirleri markalaştırmak için bu türden sanat işlerine yöneldiklerini vurgulamaktadır. Böylesine büyük yatırımları ve izleyici kitlelerini hedefleyen kurumlar, geleneksel galeri ya da müze boyutlarının sınırlarını aşan büyük ölçekli çalışmaları destekler hale gelmiştir (Manco, 2014: 15).

Ölçek konusundaki tartışmaların başlıca kaygılarından birisi sanatçıların kurumların talepleri doğrultusunda kendi sanatsal yaklaşımlarından ödün vermek durumunda kalmalarıyla ilişkilidir. Mekana özgü sanat, 1950’li yıllarda, daha çok sanat galerisi içerisindeki minimal sayılabilecek müdaleleri içermekteydi. Yves Klein, Michael Asher, Lawrence Weiner, Heimo Zobernig, William Anastasie gibi bazı sanatçılar mümkün olduğunca minimum ilavelerle, galeri mekanlarının varolan verilerini kullanmaya gayret göstermiş, böylece bir şekilde 'kurumların kendilerini kullanan bir kurumsal eleştiri' geliştirmişlerdir.

Boş bir galeri mekanının sergilenmesiyle biçimsel anlamda oldukça minimal bir öneriyle başlayan bu serüvenin, bugün artık bambaşka amaçlar doğrultusunda, yeniden kurumsallaşarak zaman zaman devasa boyutlara ulaştığı doğru. Ancak mekana özgü sanat başlığını yalnızca büyük kurumların dev bütçeli projeleriyle değerlendirmek, her 
koşulda çok da anlamlı olmayabilir. Bu türden bir değerlendirme, tüm bu tartışmalı durumlardan bağımsız, mekanların fiziksel özelliklerini kendi öznel biçimsel ve düşünsel sanat yaklaşımlarını iletmek için bir araç olarak kullananan ve bu yolda kurumsal baskılara karşı ödün vermeyen büyük bir sanatçı topluluğunu göz ardı etmek anlamına gelir.

Mekana ilişkin ya da mekana özgü sanat söz konusu olduğunda, varolan mimarinin ya da daha geniş bir kamusal alanın ölçeği elbette ki sanatçının üretiminde belirleyici bir etken. Kaldı ki teknolojik gelişmeler sayesinde, hem uygulama yöntemleri hem de materyal seçenekleri açısından sınırsız olasılıkların var olduğu bir ortamda mimari ve kamusal alan ölçeğinde 'görünür' olma arzusu çok da anlamsız bir durum değildir.

Inges Idee (Hans Hemmert, Axel Lieber, Thomas A. Schmidt and Georg Zey) kamusal alanlar için çalışmalar üreten bir sanatçı kolektifidir (Resim 8). Sanatçıların ölçeğe ilişkin kararları daima mekanın elemanlarıyla ilişkilendirilmektedir. Kolektif üyelerinden Georg Zey günümüzde 'büyük olanın iyi olduğu' düşüncesinin ekonomik pazardaki genişleme ile birlikte yaygın hale geldiğini, ancak bu anlayışın aksine sanat işine ait değerin onun boyutları ile ölçülemeyeceğine vurgu yapmaktadr. Çoğunlukla açık kamusal alanlarda gerçekleştirdikleri projeleriyle dikkat çeken Inges Idee, 'görünürlük' anahtar kelimesini merkeze alarak verili alanın ölçeğiyle diyaloğa giren işler üretmektedir. Örneğin 35 metre uzunluğunda özgün bir forma sahip elektrik direğinden oluşan Zauberlehrling, boyutlarına ilişkin referansları çevresindeki halihazırda varolan diğer direklerden almaktadır. ${ }^{13}$

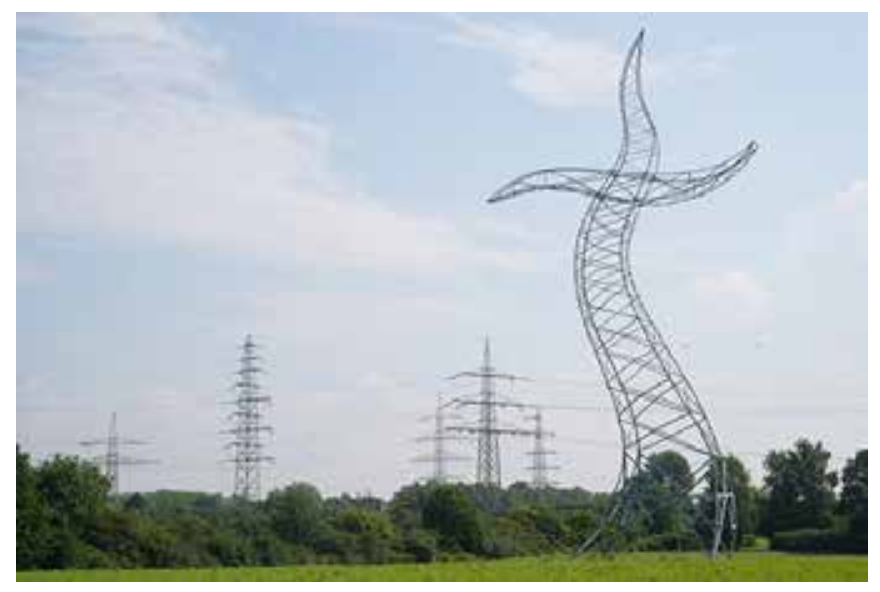

Resim 8. Inges Idee, 'Zauberlehrling', Oberhausen, Almanya, 2013.
Benzer bir durum yine bir sanatsal kolektif olarak faaliyet gösteren MSK7'nin (Mona Babl, Kati Gausmann, Ricarda Mieth, Anja Sonnenburg) projelerinde de gözlemlenebilir (Resim 9-10). Sanatçılar bir kilise için proje üretmek için davet almış, ancak yapmış oldukları tarihsel ve sosyal araştırmalar sonucunda mimarinin iç mekanı yerine etrafını çevreleyen alana uygulanmak üzere bir çalışma geliştirmişlerdir. Almış oldukları bu karar doğal olarak ve kaçınılmaz bir biçimde büyük ölçekli bir iş üretmelerine neden olmuştur. Sanatçıların Sfumato isimli bir diğer projesi de işgal ettiği alan göz önüne alındığında görece büyük ölçekli sayılabilir. Sokağı kaplayan bir sis bulutundan oluşan bu iş, ölçek anlamında minimum materyal ile maksimum etki yaratmaktadır. ${ }^{14}$

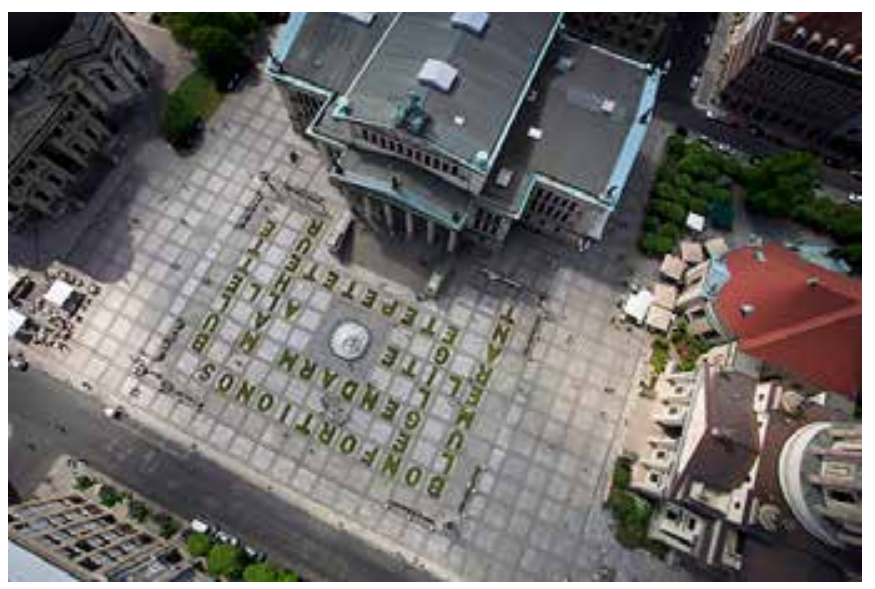

Resim 9. msk7, 'Blümerant', Berlin, Almanya, 2007.

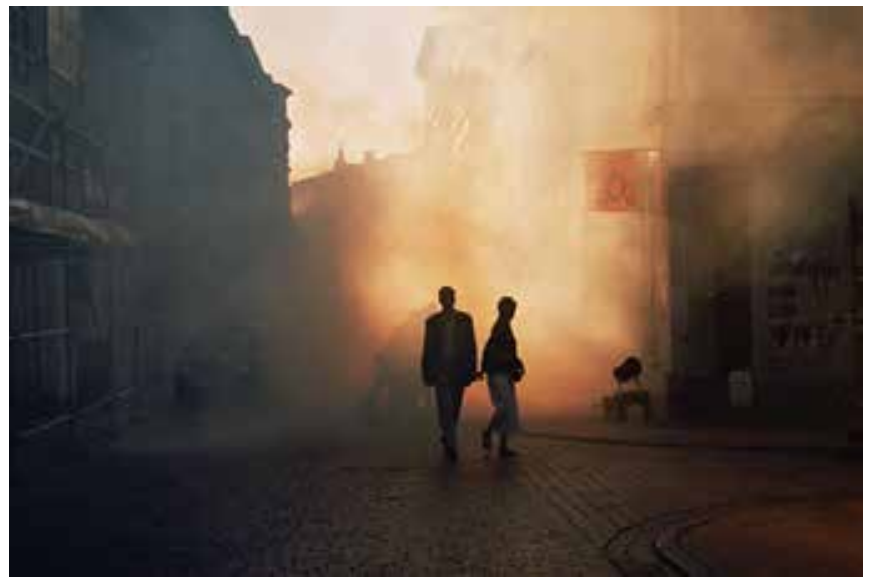

Resim 10. msk7, 'Sfumato', Schwerin, Almanya, 2005.

Örneklerden de anlaşılacağı gibi, sanat eseri ile bulunduğu alanın birbirinden bağımsız değerlendirilemediği 
bir durumu kapsayan mekana özgü işler ve özellikle açı alanlarda gerçekleştirilen müdahale çalışmaları, doğaları gereği onları çevreleyen mekansal ve atmosferik yapıyla anlam bulmaktadır. Georg Zey'in de vurguladığı üzere, buradan sanat işine ait mesajın değerinin onun ölçeği ile doğru orantılı olduğu anlamı çıarılmamalıdır elbette. ${ }^{15}$ Bugün pek çok sanatçı halen görece küçük ölçekli müdahalelerden, eklemelerden ya da yapılardan oluşan mekan bazlı çalışmalar üretmeye devam etmektedir. Ancak bu noktada devreye sokulması gereken bir diğer bileşen izleyici faktörüdür. Sanatçının müdahalesi ne kadar küçük ölçeğe sahip olursa olsun, işin gerçek boyutu izleyicinin onu yerleştirdiği perspektife göre şekil almaktadır. Bu türden çalışmaları çoğu zaman etrafında gezinerek ya da içerisinden geçerek deneyimleyen izleyiciler bu sanat biçimiyle direkt ve aktif bir ilişki kurmaktadırlar. Bu nedenle iş ve onu çevreleyen biçimsel ve tarihsel verilerin hangi ölçüde çalışmanın boyutlarını belirlediği konusu izleyicinin onu deneyimleme sürecine göre değişkenlik göstermektedir (bir bina içerisindeki yerleştirme örneğini ele alacak olursak, binaya ait tüm yapısal boyutlar, binanın içerisinde bulunduğu avlu ya da bahçe ve daha tarihsel bir kapsamda tüm bunları içerisinde barındıran şehir).

\section{5. İzleyici}

Geleneksel anlamda resim ve heykel alanında çoğunlukla sanat eserinin yalnızca kendisine ait fiziksel özellikler bir sorunsal oluştururken, mekana özgü çalışmalarda, işin bütününü oluşturan unsurların sayısı çok daha fazladır. Bu unsurlardan birisi çoğu zaman çalışmaların fiziksel koşullarının biçimlenmesi sürecinde etkin bir rol oynayan izleyicinin aktif katıımıdır. Bu durum daha çok sanat ve mimarlık yarışmalarında, varolan binanın işlevine ve kullanıcı kitlesine bağlı hareket ederken, müdahale ya da kamusal alandaki kalıcı ya da süreli işler üreten sanatçılar için çok da bağlayıcı değildir. Aksine bu türden çalışmalar üreten sanatçılar, izleyicinin beklentilerine ilişkin kesin sonuçlara vardıkları kararlar almanın, işin özgünlüğüne ve sonsuz olasılıklar sunma potansiyeline engel teşkil eden bir durum yarattığına işaret etmektedirler. Bu anlamda sanatçılar Anna Borgman ve Candy Lenk izleyicinin beklentilerini gözönüne almanın klişelerle sonuçlanacağını ifade ederken ${ }^{16}$, Eberhard Bosslet de kendisini izleyici kitlesi- nin bir parçası olarak konumlandırarak çalışmalarının ilk izleyicisi olarak nitelendirmektedir. ${ }^{17}$

Alternatif alanlarda sergilenen geçici çalışmalar ya da süreli müdahale çalışmaları için sanat işinin izleyiciyle buluşma süreci biraz daha farklı işlemektedir. Galeri ve müzede sergilenen işlerden farklı olarak, bu türden işlerin izleyici ile buluşması önceden hazırlanmış bir davet olmaksızın, rastlantısal bir süreç dahilinde gerçekleşmektedir. Dolayısıyla işin yerleştirildiği bölgede yaşayanlar ve bir şekilde bir süre için o çevrede bulunan herkes, izleyici olma potansiyeline sahiptir. Öyle ki, bazı sanatçılar bu çok olasılıklı izleyici potansiyelini çalışmalarının merkezine yerleştirdikleri kavramları oluşturmada bir çıkış noktası olarak ele almaktadırlar. Örneğin Inges Idee grubundan Georg Zey, kamusal alanlar için üretmiş oldukları işlerinde 'ikna'nın önemine işaret etmekte, bu bağlamda, sanat eserinin toplumun her kesimini karşılaması ve onlarla iletişim kurması gerektiğini belirtmektedir. Buradan hareketle Inges Idee, politika, cinsiyet, eleştiri, teknoloji ya da güç gibi belli bir hedef kitlesine yönelik spesifik bir kavrama odaklanmak yerine, durumları farklı bağlamlara yerleştirdikleri mizahi bir yaklaşım sergilemektedir. 18

Sonuç olarak, bağlamı her ne olursa olsun (fiziksel, kavramsal, estetik ya da tarihsel), mekansal ve çevresel özellikler taşıyan sanat çalışmaları izleyicinin içinde bulunduğu ortamı ve daha kapsamlı olarak onu çevreleyen dünyayı, farklı bir perspektiften yeniden değerlendirmesini sağlamaktadır (Frock, 2005: 11). Birincil işlevi göz önüne alındığında tüm mekanlar ve kamusal alanların kitlelerin kullanımına hizmet ettiği bilgisinden yola çıkarak, sanat işlerinin de bir bütün olarak kendisini tamamlayabilmesi izleyicinin katılımyla gerçekleşebilir. Özellikle kamu binaları ve kamusal alanlardaki örneklerde izleyiciler gözlemci olmak yerine işin bir parçası haline gelmektedir. Kısacası mekana özgü işlerin bütünlüğü son noktada izleyici bileşeniyle anlamlı hale gelmektedir.

\section{Finansal Destek}

Son dönemlerde çok sayıda müze ve kamu kurumunun güncel sanat işlerini bir tür sipariş yolu ile gerek iç mekanda gerekse de kamusal alanda sergilediğini görmekteyiz. Bu kurumlar sanatçılara finansal destek sağlayarak yerleştirme ya da mekana özgü sanatı da bu türden bir ısmarlama 
yöntemi ile programları içerisine dahil etmektedirler (Manco, 2014: 7-8). Çünkü artık mimari boyutlara ulaşan, kamusal mekanlarda geniş alanlara yayılan sanat eserlerinin böylesi bir finansal destekten bağımsız üretilmesi pek de olası değildir. Mekana özgü sanat söz konusu olduğunda çalışmanın fiziksel şartlarına bağlı olarak finansal anlamda bir desteğe ihtiyaç olduğunu göz önünde bulundurmak gerekmektedir. Kurumların sağladığı fonlarla, çalışmaların boyutlarına ilişkin kısıtlamalar ortadan kalkmakta, işi farklı ortamlara uyarlamak veya taşımak mümkün hale gelmektedir. Bu sayede sanatçılar daha geniş bir izleyici kitlesiyle buluşma olanağına da sahip olmaktadır.

Çoğu zaman satışı mümkün olamayan mekana özgü çalışmaların sanat galerileriyle buluşamıyor oluşu da farklı finansal destek sistemlerine duyulan ihtiyacı arttırmaktadır. Araştırmada yer alan sanatçıların birçoğunun herhangi bir sanat galerisi ile yazılı bir anlaşması bulunmamaktadır. Projelerini, genellikle özel davetli ya da açı duyurularla gerçekleştirilen yarışmalar aracılığıyla elde ettikleri finansal destekler sayesinde gerçekleştirmektedirler. Bu sanatçılarla yapılan röportajlarda konuya ilişkin yöneltilen sorular şu şekildedir: Ismarlama sistemi sanat eserinin biçimsel özellikleri konusunda belirleyici midir? Sanatçıların finansal destek sağlayan kurumların beklentilerini göz önüne alarak, yaklaşımlarından ödün vermeleri söz konusu mudur?

Kurumların sipariş ya da ısmarlama sistemini kullanarak sanatçıların üretimlerini etkiledikleri ya da işlere müdahalede bulundukları durumlarda, konuya ilişkin negatif yöndeki eleştirilerin haksız olduğunu söylemek elbette yanlış olacaktır. Ancak, Berlin'de işleyen sistemlerin (Public Art, Percent for Art) (Schönfeld, 2012: 71-96) bazı teknik önlemler ve kısıtlar dışında sanatçıların öznel üretimleri üzerinde herhangi bir baskı oluşturmadığı durumu bu araştırmanın sonuçlarından birisi olarak karşımıza çıkmaktadır.

Kurallara ve kararlara bağlı her sistemde olduğu gibi bu yapıda da bir takım sorunlu meseleler mevcut. Sanatçıların bu sisteme ilişkin problemli buldukları noktalar, özellikle zaman yönetimi, jüri seçimi, sanatçılar üzerine yüklenen sorumluluklar, yetersiz finansal destek, sigorta, gibi konular üzerine yoğunlaşmaktadır. Bahsi geçen problemlerin, özellikle kamusal alan projeleri üreten sanatçı- ların hareket alanlarını kısıtladığı söylenebilir. Ancak yine de, bahsedilen kısıtlamalar sanatçıların üretim biçimlerini kullandıkları kavramları ya da iletmek istedikleri mesajları değiştirecek düzeyde değildir. Dolayısıyla bu organizasyonların sanatçılar üzerindeki etkisinin bir baskı unsuru oluşturduğunu öne sürerek bu durumu bütünüyle olumsuz biçimde değerlendirmek her koşulda doğru değildir.

Bağımsız bir biçimde kendi sanatsal yaklaşımlarını ifade etmek adına, mekana özgü sanat pratiğini benimsemiş olan sanatçıların deneyimlerini göz önüne alarak, bu yapının bir çok yeni alternatife olanak sağladığını söylemek mümkündür. 'Yeni stratejiler' başlığı altında incelenmiş olan sanatçılar, bu anlamda pozitif bir senaryonun karakterleri olarak karşımıza çıkmaktadır. Bu sanat biçiminin üretimindeki devamlılığını sağlayabilmek adına bu projelerde yer almak, sanatçılara deneysel bir alan açmaktadır. Sonuç olarak bu çalışma kapsamında kurumun talepleri ile sanatçının yapmayı arzuladıkları arasında bir tür dengenin oluştuğu dinamik yapıdaki örnekler ele alınmıştır. Bahsi geçen pek çok sanatçı kendi bağımsız sanat deneyimlerini mekanla bir araya getirmektedir.

\section{Sonuç}

Sanat ve mekan ilişkisinin bugün geldiği noktayı anlamak çok yönlü bir kavrayışı gerektirmektedir. Günümüzde sanatçıların bizzat kendilerinin dahi, ortaya koymuş oldukları çalışmaları bir kategoriye yerleştirmekte tereddüt ettikleri, net tanımlamalardan, keskin sınırlardan kaçındıkları bir ortamda, tek bir perspektiften elde edilen verilerle ya da münferit örneklerle çok geniş bir alana yayılmış olan bu sanat anlayışını yorumlamanın bizi objektif sonuçlara ulaştırması çok da mümkün değildir. Özellikle uygulama yöntemleri ve stratejileri açısından disiplinlerin iç içe geçmiş olduğu bir yapının ürünleri olan melez çalışmaların ve deneysel formatların değerlendirilmesi, kavramların farklı pozisyonlarda (sanatçı, tasarımcı, kuratör, mimar, jüri) nasıl karşılık bulduğunun araştırılmasına bağlıdır.

Mekana özgü sanatı 1950 ve 60’lı yılların kurumsal eleştiriye yönelik kavramlarıyla değerlendirmek elbette bu sanat anlayışının ortaya çıkış sebeplerini anlamak açısından değerlidir. Ancak bugün varılan noktada, bahsi geçen kurumlar bu sanat anlayışının varolmasında ve yaygınlaşmasında etkin bir role sahip hale gelmiştir. Kısacası gerek 
sanatçıların yaklaşımları gerekse de kurumların rolleri günümüze kadar olan bu süreçte evrimleşerek dengelerin değişmesine sebep olmuştur.

Mekanın hangi hedefler doğrultusunda, hangi biçimsel yapılarla, ne tür kavramları sorgulamak adına ve en önemlisi hangi koşullar altında sanatsal pratiğe dahil olduğuna ilişkin güncel verilere dair sanat eleştrimenlerden ve tarihçilerinden farklı yorumlar mevcut. Ancak sanatçıların temelde paylaştıkları ortak durumları, sorunları ve stratejileri saptamak adına onların deneyimlerine ait bilgilere aracısız, direkt bir iletişim yoluyla ulaşmak, gerçeğe daha yakın verilerin elde edilmesini sağlamaktadır.

Bu verilere göre, 'mekan' kurumsal eleştirinin bir aracı olmak yerine, onu sanatsal üretiminin merkezine yerleştimiş olan sanatçılar sayesinde tüm varlığıyla başlı başına bir 'bütün sanat eseri' halini almıştır. Bahsedilen örneklerden de anlaşılacağı üzere, 'mekan' sanat eseri için bir uygulama ya da yerleştirme alanı olmaktan ziyade fiziksel, kavramsal, tarihsel, atmosferik, işlevsel bütün özellikleriyle sanat işinin kendisini oluşturur hale gelmiştir. Sanatçının müdahalesi çoğu zaman bu özelliklerin bir tür senteziyle ortaya çıkmakta ve mekanın varolan verileriyle paralel bir yapı sergilemektedir.

Galeri ya da müze koşullarında sergilenen sanatın geleneksel üretim biçimlerine (resim, heykel vs.) kıyasla, hem parametreler, hem göz önüne alınması gereken durumlar ve önlemler, hem de finansal meseleler bakımından görece daha karmaşık ve riskli bir konuma sahip olan mekana özgü, kamusal ya da müdahale şeklindeki sanat anlayışlarını benimsemiş olan sanatçılar, sosyal yaşamlarımızı belirleyen güncel trendler ve gelişmelerden faydalanarak mekan bilincimizi çağdaş ve estetik önerilerle doldurmaya gayret göstermektedirler.

Sonuç olarak, sanat ve mekan ilişkisinin bugün ulaştığı noktaları kavrayabilmek, çok disiplinli melez bir yapıyı çözümlemeyi, farklı konumların perspektiflerinden faydalanmayı ve sanatçıların bahsi geçen koşullara, ne türden mücadelelerle uyum sağladıklarını anlayabilmeyi gerektirmektedir.

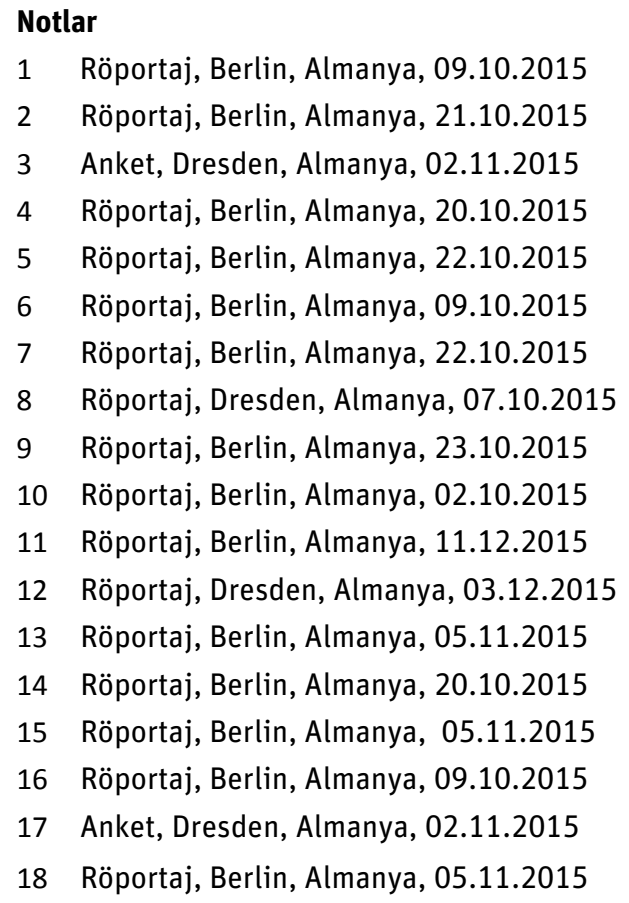

\section{Kaynakça}

Ellegood, Anne (2014). “Motley Efforts: Sculpture’s Ever-Expan ding Field”, Vitamin 3-D New Perspectives in Sculpture and Installation, Phaidon Press, London

Fernie, Jes (2006). “Introduction”, Two Minds: Artists And Archi tects in Collaboration, Black Dog Publishing, London

Foster, Hal (2011). Art and Architecture Complex, Verso, New York

Frock, Christian (2015). "Introduction: Site-Specific Installation: Some Historic Context”, Unexpected Art: Serendipitous Ins tallations, Site-Specific Works, and Surprising Interventions, ed. Jenny Moussa Spring, Cronicle Books, San Francisco

Greenberg, Reesa (2005). "The Exhibited Redistributed: a case for reassessing space”, Thinking About Exhibitions, ed. Sandy Nairne vd., Routledge, Londra-New York

Hofman, Florentijn (2015). "Preface”, Unexpected Art: Serendipi tous Installations, Site-Specific Works, and Surprising Inter ventions, ed. Jenny Moussa Spring, Cronicle Books, San Francisco

Ilfeld, Etan Jonathan (2012). Beyond Contemporary Art, Vivays Publishing, London

Irwin, Robert (1985). Notes Toward a Conditional Art, Lapis Pr, USA

Kaye, Nick (2000). Site Specific Art Performance Place and Docu mentation, Routledge, London 
Lavin, Sylvia (2011). Kissing Architecture, Princeton University Press, New Jersey

Manco, Tristan (2014). Big Art X Small Art, Thames and Hudson, London

O'Doherty, Brian (1999). Inside the White Cube: The Ideology of the Gallery Space, University of California Press, USA

Papapetros, Spyros ve Rose, Julian (2014). "Introduction” Ret racing The Expanded Field:Encounters between Art and Arci tecture, MIT Press, Cambridge MA

Rugg, Judith (2010). Exploring Site-Specific Art, I.B.Tauris \& Co Ltd, New York

Schönfeld, Martin (2012). "Berlin / Art as the Culture of Public Realm”, Thinking the City Acting the City, ed. Rainer W. Ernst and Anke Müffelmann, Muthesius Academy of Fine Arts and Design, Germany

Wallace, Isabelle Loring ve Wendl, Nora (2013). "Introduction", Contemporary Art About Architecture: a strange utility, Ashga te Publishing Limited, England

Wu, Chin Tao (2002). Privatising Culture: Corporate Art Interventi on since the 1980s, Verso, London.

\section{Görsel Kaynaklar}

Resim 1. Anna Borgman / Candy Lenk, 'Rekonstruktion', 2015

CBorgman Lenk

Resim 2. Eberhard Bosslet, 'Reformation VII', 2009

(c)Eberhard Bosslet

Resim 3. Anne Peschken / Marek Pisarsky, 'Wandering Buoy', 2005

CPeschken/Pisarsky (UrbanArt)

Reim 4. Maria Linares, 'Hirsch Rot', 2014 (c)Birgit Piramovsky

Resim 5. Svea Duwe, 'LIEBE. WAHR. JETZT’ 2014

(C) René Zieger

Resim 6. Oliver Oefelein, 'Sticky Cloud Klaipeda', 2011

(C) Oliver Oefelein

Resim 7. Nadja Schöllhammer, 'Soul Inhaler', 2105

(C)Eric Tschernow

Resim 8. Inges Idee, 'Zauberlehrling', 2103

(C) Inges Idee

Resim 9. msk7, 'Blümerant', 2007

(C) Jürgen Hohmuth/Zeitort.de

Resim 10. msk7, 'Sfumato', 2005

(C) $\mathrm{msk} 7$ 